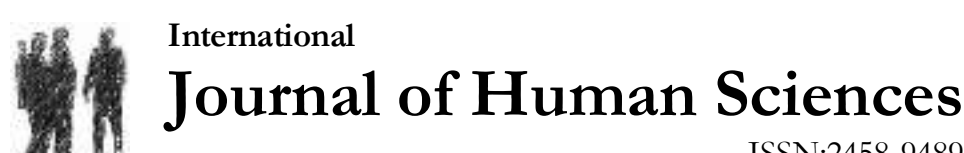 \\ ISSN:2458-9489
}

Volume 14 Issue 4 Year: 2017

\section{The effect of different training programs on throwing accuracy of elite female handball players}

\author{
Nebahat Eler ${ }^{1}$ \\ Serdar Eler ${ }^{2}$
}

\begin{abstract}
The aim of this study is to examine the acute effect of different training programs applied to elite female handball players on throwing accuracy. 14 elite female players were participated in the study. The mean age of the participating players was $28.64 \pm 9.88$ (years), the mean height length was $176.50 \pm 4.86(\mathrm{~cm})$, the mean body weight was $68.07 \pm 2.12(\mathrm{~kg})$ and the mean sport age was $14.36 \pm 4.89$ (years). On different days, a technical training program, maximal strength training program, strength endurance training program and speed power training program have been implemented to the participating players in the research. Before and after training, the players throwing the ball from their area to the specific points of goal and the percentage of accuracy was determined. As a result; there was a significant difference between before and after maximal strength training the mean values of throwing accuracy $(\mathrm{p}<0,05)$ but there was no significant difference before and after other training programs $(p>0,05)$. This result indicates that acute maximal strength training has a negative effect on throwing accuracy.
\end{abstract}

Keywords: Handball; throwing accuracy ; female; strength

\section{Introduction}

Handball is a sport branch that requires intense effort composed of defense and offensive organizations. When implementing these organizations; it includes walking, passing, bouncing, shooting, block, short distance fast running (Marques et al.,2011).Speed strength maximal force and technical skill come to the forefront in connection with these activities. (Florin et al., 2012), (Saeterbakken et al., 2011). After training, each player makes a position throwing at the handball in which the throwing is important (the throwing to the basket in the basketball, the spike in the volleyball etc.). But is the throwing practice after the applied training program appropriate for the efficiency of throwing accuracy? What is the acute effect of strength and technical training programs? Studies in this area is limited, though, in the literature survey; we found many studies about throwing in the throw area of handball, polo, and baseball. Some of these studies relate throwing performance to throwing speed and strength, some of them have investigated the effects of different training on throwing speed, and lastly some of them have examined the relation between throwing speed and throwing accuracy.(Tillaar \& Ettema, 2009), (T1llaar, 2004), (T1llaar, and Marques, 2013), (Hermassi et al., 2015), (Hermassi et al., 2011),( Gorostiaga, 2005), (Fleck et al., 1992,) and (Muijen et al.,1991).

\footnotetext{
${ }^{1}$ Ph.D., School of Physical Education and Sports, Bülent Ecevit University, Zonguldak, nebahateler@gmail.com

2 Ph.D., Faculty of Sports Sciences, Gazi University, Ankara, serdareler@hotmail.com
} 
In recent years, many studies has been made increasingly in females handball, though there is limited information about elite female handball players for coaches and sports scientists, even though the players' abilities and the need for further development of the handball (Manchado et al., 2013). Lidor (2011), Although there are studies on the relationship between throwing accuracy and throwing speed, there is very little data on throwing accuracy, indicating that accuracy is as important as speed at goal, more studies should be done and that the effect of different training programs should be investigated. Throwing performance is important for success and result in handball (Marques and González Badillo, 2010), (Gorostiag, 2005). Players must increase their chances of scoring as fast as possible to score goals. (Gorostiaga, 2005). For an effective throwing, the ball must go at the highest speed and aim at the target. Therefore, players must maintain these two parameters throughout the game (Manchado et al., 2014). While Debanne \& Laffaye (2011) indicate that throwing performance depends on the player's arm movement and ability to accelerate the ball, and accuracy is required, Tillaar (2009) indicate that throwing performance is dependent on strength and speed, and Wagner \& Müller (2008) indicate that maximum throwing speed and throwing accuracy is required. But about throwing performance; It is thought that reaching the goal in handball should include throwing accuracy. Zapartis (2007) stated that the effect of throwing ability depends on the speed and accuracy of the ball, that the players must maintain these two parameters during the competition but; the effect of these two parameters can be reduced during the game so; the regular and planned strength, speed strength and technical training programs should be implemented.

The handball's ball is smaller than other team sports' ball. There is a close relationship between ball speed and strength. In addition to the importance of the ball speed and strength, throwing accuracy factor sets the score in the handball game (Koç, 2015). It is especially important to develop strength and fitness programs so that the handball players can use their speed, accuracy and performance on the field (Kawamori \& Haff, 2004).

Strength is an important motoric feature in handball sports (Iri et al., 2003). Strength training contributes to the increase of muscle power and the development of the capacity of the body's energy production systems. Since handball is a sport with high intensity activities at high speed, success is partly due to muscle strength. Strength training programs should be routinely performed throughout the competition season to obtain muscle strength (Carvalho et al,2014). Iri et al. (2003) have found that regular speed-strength training improves throwing and jump skills in basketballers, and indicate that maximal strength training results in a 10-15\% strength development. With the fact that the team which scored more and quickly will win, the "speed-strength" motoric feature emerges as a vital important. Preparatory training programs should be implemented to improve physical, physiological and bio-motor traits as well as technical-tactical training in order to achieve success in this sport that require short-term maximal loads and in which speed strength and strength endurance combined with error-free playability (Alp, 2015). It has been seen that the strength studies with low weighted balls and those with more than normal ball weight increases throwing performance. There is no clear answer to the fact that endurance training improves throwing performance. But consultants and experts of the subject think that it may be related. Nonetheless, throwing speed can be increased by 3 times training per week during 5 weeks for general and specific endurance (Van Den Tillaar, 2004). Genevois et al. (2015)suggest that elite female handball players should develop and maintain their shoulder muscles with regular strength training, especially for players' throwing performance. Hermassi and colleagues (2015) suggested in their study related with male handball players that by applying health ball throwing program during competition period could improve the ball throwing speed and maximal upper body strength. It is seen that after 8 weeks of training, the players in the durability training group increased their throwing speed, maximal strength and muscle mass, in the group with regular throwing training only maximal force and muscle volume of the players increased, and there was no significant change in the control group. 
Eler, N., \& Eler, S. (2017). The effect of different training programs on throwing accuracy of elite female handball players. Journal of Human Sciences, 14(4), 3432-3439. doi:10.14687/jhs.v14i4.4445 this study.

The acute effects of different training programs on throwing accuracy were examined in

\section{Method}

14 female players participated voluntarily in this study (table 1). Information has been collected about their health status and their injure status. Detailed information about the issue has been given to the players involved in the study.

Table.1. Demographic features of players

\begin{tabular}{ccc}
\hline $\mathbf{n}-\mathbf{1 4}$ & Average (X) & $\begin{array}{c}\text { Standard Deviation } \\
\text { (SD) }\end{array}$ \\
\hline Age (year) & 28.64 & $\pm 2,82$ \\
\hline Sport age (year) & 14.36 & \pm 4.89 \\
\hline Height (cm) & 176.50 & $\pm 4,86$ \\
\hline Body weight (kg) & 68,07 & \pm 2.12 \\
\hline
\end{tabular}

In this study, 4 different training programs were applied on 4 different days (Technical Training Program, Maximal Strength Training Program, Strength Endurance Training Program and Speed Power Training Program) (Table.2, Table.3, Table.4, Table.5). Before and after the training program, the players bounce from their places to the determined targets and do 10 throwing. The targets are circles of $60 \mathrm{~cm}$ placed on the top and bottom corners of the left and right of the goal. The throwings achieved to target (resulting in goals) and inaccessible throwings were recorded. The percentage of 10 throwings that players made before and after each training program was calculated as percentage.

Table. 2. Maximal Strength Training Program

\begin{tabular}{|c|c|c|c|c|c|c|}
\hline No & Exercice & $\begin{array}{c}\text { Repetition } \\
\text { Number }\end{array}$ & $\begin{array}{c}\text { Number of } \\
\text { Series }\end{array}$ & Overload & Rest & Application \\
\hline 1 & angin & $4-10$ & 2 & Mid tempo- fluent & Break between Series 5-7 dk & $\% 60 \times 4-\% 50 \times 6-$ \\
\hline Half squat & & & & $\% 80-100$ & break between grade s $-1-2$ min. & $\% 45 \times 8-\% 40 \times 10$ \\
\hline 2 & & $4-10$ & 2 & Mid tempo- fluent & Break between Series 5-7 dk & $\% 27,5 \times 4-\% 25 \times 6-$ \\
\hline Bench press & & & & $\% 80-100$ & break between grade s -1-2 min. & $\% 22,5 \times 8-\% 20 \times 10$ \\
\hline 3 & & $4-10$ & 2 & Mid tempo- fluent & Break between Series 5-7 dk & $\% 40 \times 4-\% 35 \times 6-$ \\
\hline Tip toe & & & & $\% 80-100$ & break between grade s $-1-2$ min. & $\% 30 \times 8-\% 20 \times 10$ \\
\hline 4 & & $4-10$ & 2 & Mid tempo- fluent & Break between Series 5-7 dk & $\% 27,5 \times 4-\% 25 \times 6-$ \\
\hline Nape press & $r_{2}$ & & & $\% 80-100$ & break between grade s $-1-2$ min. & $\% 22,5 \times 8-\% 20 \times 10$ \\
\hline
\end{tabular}

Table.3. Speed Power Training Program

\begin{tabular}{|c|c|c|c|c|c|}
\hline No & Exercise & $\begin{array}{l}\text { Repetition } \\
\text { Number }\end{array}$ & $\begin{array}{l}\text { Number } \\
\text { Of Series }\end{array}$ & Overload & Rest \\
\hline 1 & $\begin{array}{l}\text { Back lying position on bench Stretching arms } \\
\text { from back to forth and up with 10-15 kg weight }\end{array}$ & $20-30^{\prime}$ & $2-3$ & High tempo- explosive & $40-60^{\prime}$ full resting principle \\
\hline 2 & Jumping legs streched with $20-30 \mathrm{~kg}$ weight & $20-30^{\prime}$ & $2-3$ & High tempo- explosive & 40-60' full resting principle \\
\hline 3 & Peck-knife move with medicine ball & $20-30^{\prime}$ & $2-3$ & High tempo- explosive & $40-60^{\prime}$ full resting principle \\
\hline 4 & $\begin{array}{l}\text { Back lying position on bench Stretching arms } \\
\text { from back to forth and up with } 10-15 \mathrm{~kg} \text { weight }\end{array}$ & $20-30^{\prime}$ & $2-3$ & High tempo- explosive & $40-60^{\prime}$ full resting principle \\
\hline 5 & $\begin{array}{l}\text { Opening and closing arms in accordance with } \\
\text { the handball throwing technique with } 2 \times 5 \mathrm{~kg} \text { dumbbells }\end{array}$ & $20-30^{\prime}$ & $2-3$ & High tempo- explosive & $40-60^{\prime}$ full resting principle \\
\hline 6 & $\begin{array}{l}\text { With 5-7 kg weight vest jump on case with } \\
\text { two legs, get streched and get down }\end{array}$ & $20-30^{\prime}$ & $2-3$ & High tempo- explosive & $40-60^{\prime}$ full resting principle \\
\hline
\end{tabular}


Eler, N., \& Eler, S. (2017). The effect of different training programs on throwing accuracy of elite female handball players. Journal of Human Sciences, 14(4), 3432-3439. doi:10.14687/jhs.v14i4.4445

\section{Table.4. Strength Endurance Training Program}

\begin{tabular}{|c|c|c|c|c|c|}
\hline No & Exercise & $\begin{array}{l}\text { Repetition } \\
\text { Number }\end{array}$ & $\begin{array}{l}\text { Number } \\
\text { Of Series }\end{array}$ & Overload & Rest \\
\hline 1 & $\begin{array}{l}\text { Back lying position on bench Stretching arms } \\
\text { from back to forth and up with } 10-15 \mathrm{~kg} \text { weight }\end{array}$ & $20-30^{\prime}$ & $2-3$ & High tempo- explosive & $40-60^{\prime}$ full resting principle \\
\hline 2 & Jumping legs streched with $20-30 \mathrm{~kg}$ weight & 20-30' & $2-3$ & High tempo- explosive & 40-60' full resting principle \\
\hline 3 & Peck-knife move with medicine ball & $20-30^{\prime}$ & $2-3$ & High tempo- explosive & $40-60^{\prime}$ full resting principle \\
\hline 4 & $\begin{array}{l}\text { Back lying position on bench Stretching arms } \\
\text { from back to forth and up with } 10-15 \mathrm{~kg} \text { weight }\end{array}$ & $20-30^{\prime}$ & $2-3$ & High tempo- explosive & $40-60^{\prime}$ full resting principle \\
\hline 5 & $\begin{array}{l}\text { Opening and closing arms in accordance with } \\
\text { the handball throwing technique with } 2 \times 5 \mathrm{~kg} \text { dumbbells }\end{array}$ & $20-30^{\prime}$ & $2-3$ & High tempo- explosive & $40-60^{\prime}$ full resting principle \\
\hline 6 & $\begin{array}{l}\text { With 5-7 kg weight vest jump on case with } \\
\text { two legs, get streched and get down }\end{array}$ & $20-30^{\prime}$ & $2-3$ & High tempo- explosive & $40-60^{\prime}$ full resting principle \\
\hline
\end{tabular}

Table.5. Technical Training Program

\begin{tabular}{ll}
\hline $20 \mathrm{~min}$. & Warm-up \\
\hline $15 \mathrm{~min}$ & Collected passing exercise \\
\hline $15 \mathrm{~min}$ & Running reciprocal and passing and throwing at the goal \\
\hline $20 \mathrm{~min}$ & $2 \times 1-3 \times 2$ offense - defense exercise \\
\hline $20 \mathrm{~min}$ & $6 \times 6$ offense -defense exercise \\
\hline $10 \mathrm{~min}$ & Stretching \\
\hline
\end{tabular}

Statistical Analysis

Average throwing accuracy percentages before and after different trainings were examined with Wilcoxon test. Friedman test was used to identify average throwing accuracy percentages before different training types and whether difference between these averages was significant, in case of there was a significant difference, groups were compared dyadically with wilcoxon test to determine which group was the source for difference. Kruskal Wallis test was performed to determine average throwing accuracy percentages according to position before and after different training programs and whether the difference between these averages was significant. Since the number of data was limited and did not show normal distribution, non-parametric tests were used. The analysis of data was made in SPSS 20.0 program with $\% 95$ trust level.

\section{Results}

According to test results; there was a statistically significant difference between the mean percentiles of throwing accuracy before and after the maximal strength training program $(p<0,05)$, while there was no statistically significant difference between the values before and after other training programs $(p>0,05)$. The average of throwing accuracy before maximal strength training was $67,14 \%$, while the average after training was $49,2 \%$. There is no statistically significant difference although the average of throwing scores are close in before and after the technical training (64.29-65\%) and the speed-power training programs (62.14- 59.29\%). Before and after strength endurance training program $(66.43-60.71 \%)$, the average of throwing accuracy decreased but it was not statistically significant. (Table 5) (Graph 1). 
Eler, N., \& Eler, S. (2017). The effect of different training programs on throwing accuracy of elite female handball players. Journal of Human Sciences, 14(4), 3432-3439. doi:10.14687/jhs.v14i4.4445

Table.6. Comparison of Throwing Accuracy Averages Before and After Different Training Programs

\begin{tabular}{|c|c|c|c|c|c|c|}
\hline & & $\mathrm{N}$ & $\begin{array}{c}\text { Average } \\
(\%)\end{array}$ & $\begin{array}{c}\text { Std. } \\
\text { Deviation }\end{array}$ & W & $\mathrm{p}$ \\
\hline \multirow{2}{*}{ Technical Training } & Before & 14 & 64,29 & 8,52 & \multirow{2}{*}{24} & \multirow{2}{*}{0,855} \\
\hline & After & 14 & 65 & 10,92 & & \\
\hline \multirow{2}{*}{$\begin{array}{l}\text { Maximal Strength } \\
\text { Training }\end{array}$} & Before & 14 & 67,14 & 13,83 & \multirow{2}{*}{2,5} & \multirow{2}{*}{$0,001 *$} \\
\hline & After & 14 & 49,29 & 9,97 & & \\
\hline \multirow{2}{*}{ Speed Power Training } & Before & 14 & 62,14 & 12,51 & \multirow{2}{*}{20,5} & \multirow{2}{*}{0,458} \\
\hline & After & 14 & 59,29 & 16,39 & & \\
\hline \multirow{2}{*}{$\begin{array}{c}\text { Strength Endurance } \\
\text { Training }\end{array}$} & Before & 14 & 66,43 & 11,51 & \multirow{2}{*}{8} & \multirow{2}{*}{0,075} \\
\hline & After & 14 & 60,71 & 10,72 & & \\
\hline
\end{tabular}

There is no significant difference among average throwing accuracy percentages before different training programs (Table.6).

Table.7. Comparison of Throwing Accuracy Averages According to Training Programs Before Training

\begin{tabular}{cccccc}
\hline & $\mathrm{N}$ & Average & $\begin{array}{c}\text { Std. } \\
\text { Deviation }\end{array}$ & $\begin{array}{c}\text { Friedman test } \\
\text { value }\end{array}$ & $\mathrm{p}$ \\
\hline Technical Training & 14 & 64,29 & 8,52 \\
\hline Maximal Strength Training & 14 & 67,14 & 13,83 \\
\hline Speed Power Training & 14 & 62,14 & 12,51 \\
\hline Strength Endurance Training & 14 & 66,43 & 11,51 & & \\
\hline
\end{tabular}

There is no significant difference between the mean percentages of throwing scores before different training programs (Table 6).

There is a significant difference among average throwing accuracy percentages after different training programs $\left({ }^{*} \mathrm{p}<0,05\right)$. Throwing accuracy average after Maximal Strength Training Program is significantly lower than throwing accuracy average obtained after Continuity on Technique and Strength Training Programs. There is no significant difference among other training programs (Tablo.7).

Table.8. Comparison of Throwing Accuracy Averages According to Training Programs After Training

\begin{tabular}{|c|c|c|c|c|c|}
\hline & $\mathrm{N}$ & Average & $\begin{array}{c}\text { Std. } \\
\text { Deviation }\end{array}$ & $\begin{array}{l}\text { Friedman test } \\
\text { value }\end{array}$ & $\mathrm{p}$ \\
\hline Technical Training & 14 & 65 & 10,92 & \multirow{4}{*}{12,095} & \multirow{4}{*}{$0,007^{*}$} \\
\hline Maximal Strength Training & 14 & 49,29 & 9,97 & & \\
\hline Speed Power Training & 14 & 59,29 & 16,39 & & \\
\hline Strength Endurance Training & 14 & 60,71 & 10,72 & & \\
\hline
\end{tabular}

\section{Discussion}

Hermassi and colleagues (2015) suggested in their study related with male handballers that by applying health ball throwing program during competition period could improve the ball throwing speed and maximal upper body strength. It is seen that after 8 weeks of training, the players in the endurance training group increased their throwing speed, maximal strength and muscle mass, in the group with regular throwing training only maximal force and muscle volume of the players increased, and there was no significant change in the control group. 
In another study; physical and physiological characteristics of handball players who play amateur, professional and national team, shooting speeds and their throwing and their performance on the field have been examined. Particularly in professional and national team players, the throwing accuracy is increased while throwing strength is decreased. Kawamori \& Haff (2004) concluded that it is important for handball players to develop strength and fitness programs in order to use these parameters effectively.

Also, Juan et al.; in their study; investigated the relationship between throwing speed and throwing accuracy by giving different application instructions to amateur and professional handballers. The professional handballers' throwing speed and accuracy performances are better than amateurs. This result is parallel to the studies that Etnyre (1998) and Tillaar and Ettema (2006) have done.

Zapartidis et al. 2009, in their study of 16 female handball players, during a 60-minute game period, the players made 3 shots at a distance of $7 \mathrm{~m}$ every 10 minutes and they recorded a significant decrease in their final throws. The study showed that the players' efforts during the competition reduced both effects of ball speed and ball hit.

In another study conducted on 40 university students with a mean age of $15.9 \pm 1.0$, the first group was not applied training program, the second and third groups had strength training with different weighted health ball and after 8 weeks, significant difference was detected in the 2nd and 3rd group about throwing speed (T1llaar and Marques, 2013).

In study of Hoff and Almasbakk, in addition to regularly handball training for 9 weeks, the bench press study concluded that the players in the experimental group increased their throwing speed by jumping (17\%) and by standing $(18 \%)$ and there was no significant increase in the control group.

Throwing efficiency refers to throwing strength and throwing accuracy. The studies showed that regular strength training increased the throwing strength and speed. It is seen in the literature review that there was a significant correlation between throwing strength and throwing speed when regular strength training was applied. In this study, it was determined that the maximal strength training, pre- and post-training throwing accuracy values significantly decreased and has a significant difference compared to the technical, speed-power and strength endurance training programs. This means that acute maximal strength training programs have a negative impact on throwing accuracy. It has been determined that the average values before and after the technical training and speed power training programs are close to each other. Statistically, the results are not significant, but they show that there is not a big difference in the mean value of the throwing accuracy after the technical and speed power training programs. We can say that there is no positive-negative effect of throwing exercises made after technical training and speed power training. It was observed that the average values before and after the strength endurance training program decreased but there was no statistically significant effect on throwing accuracy.

\section{Conclusion}

In this study, the acute effect of the different training programs applied to the elite female handball team on throwing accuracy was examined. A significant decrease was observed in the average of the throwing accuracy before and after the maximal strength training program. The average of throwing accuracy after maximal strength training was significantly different according to the technique, speed power and strength endurance programs. Maximal strength is shown as the highest value that player can take in one trial (Çelenk 2003, Bompa 1998, Dündar 1994, Sevim 2009). Maximal strength training may result in muscularly fatigue players because it is a strength training method in which the load density is intense. It is thought that it has a negative effect on throwing accuracy due to this muscular fatigue. These result clearly show that throwing exercises made at the end of the strength training were not fruitful, and especially after the technical, speed strength and strength endurance training programs have no meaningful effect. 
Eler, N., \& Eler, S. (2017). The effect of different training programs on throwing accuracy of elite female handball players. Journal of Human Sciences, 14(4), 3432-3439. doi:10.14687/jhs.v14i4.4445

\section{References}

Alp M, Kılınç F, Suna G. (2015). Hazırlık sezonunda hentbolculara uygulanan antrenmanların bazı antropometrik ve biyomotorik özellikler üzerine etkisinin incelenmesi. Akademik Spor Sağlık ve Tip Bilimleri Dergisi, 17(2), 24-33.

Bompa Tudor. O. (1998). Antrenman Kuramı ve Yöntemi. (Çev. İlknur Keskin, A. Burcu Tuner) Bağırgan Yayımevi. s: 370-457.

Carvalho VJA, Mourão P, Abade E. (2014). Effects of strength training combined with specific plyometric exercises on body composition, vertical jump height and lower limb strength development in elite male handball players: a case study Journol Of Human Special Issue, 41, 125-132.

Çelenk B. (2003). Voleybol'da sürat", http// www.voleybolum.com.

Debanne T and Laffaye G. (2011). Predicting the throwing of the ball in handball with anthropometric variables and isotonic tests. J Sports Sci., 29,705-713.

Dündar U. (1994). Antrenman Teorisi. Ankara. Bağırgan Yayımevi. s: 50-67 .

Etnyre, B.R. (1998). Accuracy characteristics of throwing as a result of maximum force effort. Perceptual Motor Skills, 86, 1211-1217.

Florin C, Constantin R, Adrian G. (2012). The motric structure and dynamic of handball ,Ovidius University Annals, Scries Physical Education and Sport / Science, Movement And Health, Vol. XII, ISSUE 2 Supplement.

Garc1'A JA, Sabido R, Barbado D, \& Moreno FJ. (2013). Analysis of the relation between throwing speed and throwing accuracy in team-handball according to instruction. European Journal of Sport Science, 13 (2), 149-154.

Genevois C, Berthier P, Guido V, Muller F, Thiebault F and Rogowski I. (2014). Effects of 6-week sling-based training of the external-rotator muscles on the shoulder profile in elite female high school handball players. Journal of Sport Rehabilitation, 23,286-295.

González-Badillo JJ, Marques MC. (2010) relationship between kinematic factors and countermovement jump height in trained track and field athletes. J. Strength Cond. Res., 24 (12), 3443-3447.

Gorostiaga E. M., Granados C., Ibanez J., \& Izquierdo M. (2005). Differences in physical fitness and throwing velocity among elite and amateur male handball players. International Journal of Sports Medicin, 26, 225-232.

Hermassi S, Van Den Tillaar R, Khlifa R, Chelly MS, and Chamari, K. (2015). Comparison of inseason-specific resistance vs. a regular throwing training program on throwing velocity, anthropometry, and power performance in elite handball players. Journal of Strength and Conditioning Research, 29(8), 2105-2114.

Hoff J and Almasbakk B. (2003). The effects of maximum strength trainingon throwing velocity and muscle strength in women's teamhandball players. J Strength Cond Res. 1995; 9: 255258.

İri R, Başlamışlı A, Göksu ÖC. İ.Ü Spor Bilim Dergisi, 11(3), 47-52.

Juan AG, Sabido R, Barbado D, \& Moreno FJ. (2013). Analysis of the relation between throwing speed and throwing accuracy in team-handball according to instruction, European Journal of Sport Science, 2013, European Journal of Sport Science, 13 (2), 149-154.

Kawamorı N and Haff GG. (2004). The Optımal Training Load For The Development Of Muscular Power, Journal of Strength and Conditioning Research, 18(3), 675-684.

Koç H. (2015). Study of the impact of palmaris longus muscle on shooting velocity in handball players. Erciyes University School of Physical Education and Sports, Kayseri, Turkey Anthropologist, 20(3), 651-655.

Manchado C, Tortosa J -Mart1'Nez, Vila H, Ferragut and Platen P. (2013). Performance factors in women's team handball: physical and physiological aspects-a review. Journal of Strength and Conditioning Research, 27(6), 1708-1719. 
Eler, N., \& Eler, S. (2017). The effect of different training programs on throwing accuracy of elite female handball players. Journal of Human Sciences, 14(4), 3432-3439. doi:10.14687/jhs.v14i4.4445

Marques MC, Saavedra FJ, Abrantes C, Aidar JF. (2011). Associations between Rate of Force Development Metrics and Throwing Velocity in Elite Team Handball Players: a Short Research Report, Journol of human special Issue, 53-57.

Noutsos K, Nassis, G, Vareltis I, Kororos P, Skoufas D., \& Bayios I. (2008). Physiological and anthropometric characteristics of elite junior handball players. Communication to the Annual Congress of the European College of Sport Science, Estoril, Portugal, 128.

Saeterbakken AH, Van Den Tillaar R and Seiler. (2011). Effect of core stability training on throwing velocity in women's handball players. J Strength, 25,712.

Sevim Y. (2009). Antrenman Bilgisi. Ankara. Nobel Yayın Dağıtım.

Van Den Tillaar R.( 2004). Effect of different training programs on the velocity of overarm throwing: A Brief Review, Journal of Strength and Conditioning Research, , 18(2), 388-396.

Van Den Tillaar R and Ma' Rio C. Marques RC. (2013). Effect of different training workload on overhead throwing performance with different weighted balls. Journal of Strength and Conditioning Research. 27(5), 1196-1201.

Zapartidis I, Gouvali M, Bayios I and Boudolos K. (2007). Throwing effectiveness and rotational strength of the shoulder in team handball. J Sports Med Phys Fitness, 47, 169.

Zapartidis I, Skoufas, D, Vareltzis, I, Christodoulidis, T, Toganidis, T, and Kororos, P. (2009) Factors influencing ball throwing velocity in young women's handball players. Open Sports Med J., 3, 39-43.

Ziv \& Ronnie Lidor. (2009). Physical characteristics, physiological attributes, and on-court performances of handball players: A Review, European Journal of Sport Science, 9(6), 375386. 